\title{
The Development of Curriculum for Girls in Saudi Arabia
}

\author{
Fahad Alharbi \\ The University of Kansas, Lawrence, USA \\ Email: fahad2009@ku.edu
}

Received 14 October 2014; revised 10 November 2014; accepted 26 November 2014

Copyright (C) 2014 by author and Scientific Research Publishing Inc.

This work is licensed under the Creative Commons Attribution International License (CC BY). http://creativecommons.org/licenses/by/4.0/

(c) (i) Open Access

\section{Abstract}

This paper illustrates the development of curriculum for girls in Saudi Arabia and how it has changed and been challenged over time. Several factors have played important roles on impeding girls' education. Society was the main impediment, as it used to refuse any change and fight that change. Girls in Saudi Arabia are segregated from boys in different schools, but in the past, they also had to take different subjects and curriculum that what boys were studying. There are three major challenges that girls' education faced until they were given the same quality of education that boys received. The first challenge started during King Faisal's era when girls were allowed to go to public schools but under different directors than boys' institutions. The second time was in 2002, when the girls' education was moved under the Ministry of Education. The last challenge began with King Abdullah's project for developing education, whereupon girls received the same quality of education as men.

\section{Keywords}

\section{Curriculum, Society, Girls' Education, Religious Men}

\section{Introduction}

Education is a basic need for all people in every country without consideration of their social class, race, gender, or religion. However, those groups are sometimes negatively stereotyped in the schools, as some people do not get equal education because they are threatened based on their social class, race, or gender (Steele, 1997). In Saudi Arabia, girls have struggled to get rights for receiving an education. The society oppressed girls by not giving them a chance to have the same opportunity that was given to boys. Saudi Arabia is a conservative country, which is especially true in the middle regions of the country, where the full power of society resides. 


\section{Official Education in Saudi Arabia}

Official public education in Saudi Arabia was established in 1925, and it was placed under the Director of Knowledge. The public school was only for boys, as girls were not allowed to enroll in public school. During that time, girls were taught at home, which is called "Ktateb", where a scholar woman taught her students at her home, covering subjects such as religious studies and language (Hamdan, 2005). At that time, some girls tried to get their education from the public school system, especially girls, who were from the west and the east coast areas of the country. Before analyzing women's education in Saudi Arabia, it is important to know the structure of Saudi Arabian society and understand that the role of tradition and religion is vital to interpreting social change in the country, especially as it relates to women (Hamdan, 2005). Saudi Arabia is composed of five areas: east, west, south, north of the country. The east and west areas are multicultural and have people from different social classes, so they are less conservative than the other parts of the country; this means most girls who were fighting for their education were from the east and west areas of the country. This effort was confronted strongly by society, especially religious men, who thought girls should not have the same opportunity as boys. Smith states, "[w]e are not talking about prejudice or sexism as particular bias against women or a negative stereotype of women. We are talking about the consequence of women's exclusion from a full share in the making of what becomes treated as our culture" (Smith, 1987: p. 20). In fact, there are three different explanations for why society fought girls' education.

The first explanation is that religious men believed that by allowing girls to study at public schools, Saudi society would be exposed to the West and its culture, and then the Saudi society would be negatively affected (AlMunajjed, 1997). In fact, the religious men usually believed that any item or any idea imported from Western culture was not to be trusted, even though society might be in need of that idea.

The second explanation is that if girls were allowed to study in public school, society would be in danger, because the main role of women is to raise children and be a good mother (Hamdan, 2005), Therefore, the structure of the Saudi family would be threatened by women's education. Unfortunately, this argument was not only used in Saudi Arabia, but it has also been prevalent in most areas of the world when women have been fighting for their education. In the United States, some communities thought the role of women is to raise children, not obtain higher education. Therefore, women struggled to find housing on campus because they were not welcome inside campus, and they did not receive what the men on campus received. Not only that, but they also did not get jobs after finishing their bachelor degrees, so they ended up staying at home as housewives or mothers (Gordon, 1987).

The third explanation is related to religion, as most men in Saudi society, especially religious men, believed women should stay at home. They are not allowed to be out of their home unless they have a convincing reason, such as seeing a doctor or buying groceries for their homes. This idea developed because religious men thought if women were allowed to leave their home, society would become corrupt because women would deal and talk with strange men, which is against religion as they believed it. Therefore, girls were fighting for their education for more than forty years to be part of the public school system. After this historical explanation, this paper will illustrate the three major challenges for girls' education in Saudi Arabia including how the curriculum has been reformed from time to time.

\section{Girls' Curriculum in $\mathbf{1 9 6 0}$}

Without persuading religious men in the country and getting their support, it was impossible to establish girls' education in Saudi Arabia. Therefore, “[i]n 1959, King Saud discussed the issue of educating women in Saudi Arabia, and he sought support from religion's scholars to start education for girls” (Alamri, 2011: p. 88). In 1960, King Faisal issued a decision that announced the establishment of girls' public schools. In the middle of the country, especially in Buriadah, people were against the King's decision, so they went out with their guns to close any girls' school in their city by force (Hamdan, 2005). After that, they met the King and asked him to cancel his decision. According to Lacey, “whenever King Faisal faced resistance” He would ask, "Is there anything in the Holy Quran which forbids the education of women?” He would further state, "We have no cause for argument, God enjoins learning on every Muslim man and women” (Lacey, 1981: p. 368). At the end of the meeting, the King told them they were not obligated to enroll their girls in public school. In fact, for pacification of the religious men, the King established an education institution for girls' education that was separate from the Ministry of Knowledge for boys. The head and director for girl's education institution was “The Mufti of the 
Country," who was also the head of religion of the country. Therefore, these groups made the decisions regarding how girls' education should look.

In the Girls' Education Constitution, the religious men indicated that the purpose of educating a girl, as stated by the Directorate General, was "to bring her up in a proper Islamic way so as to perform her duty in life, be an ideal and successful housewife and a good mother, ready to do things which suit her nature as teaching, nursing, and medical treatment” (Alireza, 1987). Also, in another article, they wrote that girls must be separate from boys' schools at all education level except kindergarten (Alireza, 1987). Those schools were guarded by men to prevent any man from entering those schools. Amani states, "Each girls' school, college or university is assigned at least two men who are usually in their $50 \mathrm{~s}$ or $60 \mathrm{~s}$ who are responsible to check the identity of those who enter the school, deliver and pick up the mail and generally to safeguard the girls inside the school until they are picked up by their fathers or brothers” (Hamdan, 2005: p. 50).

Even though society, knowledge, and students can be a source of curriculum (Tanner, D., \& Tanner, L. N., 1975), girls in Saudi Arabia were ignored and were not asked about their needs or their interests. Smith states that in regards to women's education in Saudi Arabia, "women need to learn to relate to one another and treat each other as sources of knowledge” (Smith, 1987: p. 35). Dewey believed it is very important to relate curriculum to students' interests and experiences (Dewey, 1902). At that period of time in Saudi Arabia, boys were the only ones who appeared to benefit from girls' education because schools were preparing girls to be good wives for their husbands. Therefore, girls at that time were taught a different curriculum from boys because the purpose of schooling was different. According to Tanner, D., \& Tanner, L. N. (1975), the purpose of school is for preparing students for him or herself, a career, and citizenship. For boys, the purpose includes all three purposes with a different balance. However, the purpose for women in Saudi Arabia was only preparing her for herself. Because girls were not allowed to work at any job or to offer any thing for their country as a part of citizenship, schools only prepared them to be a good wife and mother. At that time, what was considered most worthwhile was to teach Islamic studies, Arabic language, basic math and housekeeper. The content of those curricula was totally different from what boys are taught because they are offered from different institution. The Ministry of Knowledge, which was for boys, has people who created the curriculum who were very well educated and held education degrees. On the other hand, people who created women's curriculum were religious and did not hold a degree or have knowledge on designing curriculum. In fact, when I analyzed the language curriculum from that time, I found that I was confused when I tried to find the objective or the goals of curriculum. It appears that society was afraid to give anyone a chance to lead girls' education except religious men. Women who graduated from public school stayed at home or received training to be a teacher for a girl's school.

One purpose of high school is preparing students for college (Tanner, D., \& Tanner, L. N., 1975). Higher education was established in Saudi in 1949 when the Islamic college started enrolling students for first time, and in 1957, King Saud University was found and started enrolling students in several colleges (Hakeem, 2012). However, higher education was only for boys, and girls were prevented from getting higher education. Therefore, boys' schools were improved to reach the higher education criteria. In 1969, the girls' education institution found that they had a shortage of teachers, so they decided to establish girls' teacher colleges in order to employ those girls for their schools (Hakeem, 2012). Unfortunately, girls were not allowed to take any major as was the case for men; the only major they could study at those colleges was teaching and basic courses such as cooking. That affected the curriculum they were taught girls' teaching colleges because it was only focused on one purpose, which was preparing for teaching and ignoring the other proposes of schooling, that are citizenship and self. From 1960 until 1969, women received some rights to attend public schools and higher education. Even thought they did not have equal opportunities compared to men, it was great improvement inside the very conservative society.

\section{Girls' Curriculum after $9 / 11$}

The situation of the isolation of the institutions of girls' education from boys' education was stabled for more than thirty years. Girls' schooling in elementary, secondary, high school and university remained under the Department of Religious Guidance until 2002, while the education of boys was overseen by the Ministry of Education (Hamdan, 2005). After the attacked of 9/11, the country came under criticism, especially for women's rights:

The Gulf Wars have also drawn world attention to the events in the Gulf nations and to the status of women in 
that part of the world. Ironically, the events of 9/11 brought to light again and more powerfully than ever before the issue of women's rights in Saudi society. In the aftermath of 9/11, the Saudi system in general and its religious education system in particular became the focus of much criticism. One question put forward by Prokop captures the essence of that criticism. Prokop asked to what extent the education system had been shaped and used by religious, political, and socioeconomic forces and interests (Hamdan, 2005: p. 56).

Most criticism centered on schools and curriculum because it might have influenced the output of terrorism. Therefore, Islamic radicalism was blamed, and many educators petitioned the Saudi government to reform its curriculum (Elyas \& Picard, 2013). From that time, the battle was established between the liberalism lobby and the religious men in the terms of curriculum. Each side thought they represented society and wanted to use their agenda to develop curriculum. In 2002, the liberals found that it was a time to release girls' education from religious men. According to Hamdan, “In 2002, the General Presidency for Girls’ Education and the Ministry of Education were amalgamated as a result of requests from both the general public and the government after a fire in March 2002 in an elementary girls’ school in Mecca resulted in the death of 15 young girls” (2005: p. 44). People were angry about that decision because they believed it was the first step to changing the society, and girls and boys could be integrated at the same schools in future.

Even though girls' schools were now under the Ministry of Education, they were not receiving education in the same subjects as boys. The content of curriculum for girls still focused on how to be a good mother and ignored other important issues in women's lives in Saudi Arabia, such as how to be a good leader. As an example, girls were not allowed study any sport subjects because society was afraid if girls' were given a chance to play sports that might affect her negatively. Even thought Islam does not prevent girls from playing sports, the culture had power to prevent this because it was not acceptable for women to play sports even in closed buildings where men were not allowed to get in.

Another subject that has been disregarded for girls is citizenship education; even though boys are taught citizenship from first grade through twelfth grade, girls were not taught this subject at all. I believe that because the society still did not believed that women could serve in any role for their country as a part of their citizenship. Not only were girls prevented from taking those subjects, but also they did not have a chance to attend vocational schools even though it is as important as academic subjects (Tanner, D., \& Tanner, L. N., 1975). The number of girls who enrolled in public school was almost equal to the number of boys, but girls did not receive the quality of curriculum and subject. Also, girls were not allowed to practice any kind of marketing or work in positions such as a cashier. Even though the society was changing gradually, it was still impossible for women to work beside men in public. Therefore, girls did not take any class or skills about how markets work that boys were taking. Even though girls' education was under the Ministry of Education, it could not change the curriculum, not only for girls but also for boys, because of the expected reaction of society, especially religious men.

After 2001, women's higher education began flourishing, and now most universities have a campus for girls. Also, girls could now major in medicine, biology, and computer science in most of those campuses. However, even though there were many campuses for girls around the country, they still were not allowed to attend every class at some colleges. For example, girls' campuses did not have engineering colleges, and the reasoning was that even if they offered that degree, girls would not have a chance to work in that field when they graduated. Moreover, society made the decision about what girls should take and what they should not, so society did not accept that girls could take the same courses that boys were going to take. Therefore, when girls were preparing for the college level they were not prepared like boys. For example, when I asked my sisters what do they want to be after graduating from high school they said that "there is no choice for us, we are obligated to be a teacher" while my brothers could make choices to be what they wanted to. It seems girls and boys were operating differrently at school. According to Lloyd, Mensch, and Clark (2000: p. 113) “[m]uch research on the determinants of school enrollment, retention, and ultimate grade attainment in developing countries has been confined to an exploration of the role of individual and family factors, often with particular attention given to the ways in which these factors may operate differently for boys and for girls”.

\section{King Abdullah's Project}

The last challenge and development for girls’ education started with era of King Abdullah. In 2006, the King announced the project of development education. The aims of the project are to increase the capacity of Saudi Arabia to be competitive and to build a knowledgeable society through a variety of programs, including the fol- 
lowing:

- Building an integrated system of educational standards, calendar, and accounting.

- Head the implementation of the programs for the development of education, including the following five points:

1) Continuing professional development for all those working in education.

2) Development of curricula and learning materials.

3) Improve the school environment to enhance learning.

4) Use information technology to improve learning.

5) Develop non-classroom activities and student services.

(Mashroa Almalek Abdullah Ltatwer Atalyem, 2012).

Those aims were for both girls and boys, so the first development was that they should have the same curriculum and that it should be revised to meet international standards. Once again there was opposition, especially from religious men, because they thought it was impossible for girls to study the same subjects that boys are taking. However, the power of the religious men inside society is weaker than it was before. Also, in 2009, King Abdullah decided to give women a chance to be Ministry Education leaders. Dr. Noura al-Fayez is Deputy Minister of Education Affairs for girls. That means that at this time girls are perceived in the same manner that boys are. For example, now girls are allowed to play sports inside their some schools, which was impossible ten years ago. The quality of curriculum that boys were given is the same for girls right now.

This improvement is not only at K-12 level but also at the higher education level. In 2006, King Abdullah's scholarship was established. The scholarship is offered for study in universities around the world. Girls are given same chance that boys are, with more flexibility for girls. According to the Ministry of Higher Education "Currently, more than 300 higher education colleges exist for women in the country alongside universities, and women represent more than $56.6 \%$ of the total number of Saudi university students and more than $20 \%$ of those benefiting from overseas scholarship program.” (Ministry of Higher, 2010) With scholarship girls are allowed to major in the same fields as are boys. For example, they can be lawyers or engineers, which was impossible for them 10 years ago.

\section{Conclusion}

Girls' education in Saudi Arabia has confronted many problems as girls have tried to establish their rights to a quality education. Over time, girls' curriculum was changed based on several factors, including society's reactions. The curriculum still needs considerable work in order to be developed to be appropriate for contemporary life. The future appears bright because educators in Saudi Arabia are sharing interactions with education leaders from countries such as the United States, Germany, and Japan: This means that Saudi Arabia educators can benefit from them in order to improve its school system.

\section{References}

Alamri, M. (2011). Higher Education in Saudi Arabia. Journal of Higher Education Theory and Practice, 11, 88-91.

Alireza, M. (1987). Women of Saudi Arabia. National Geographic, 172, 422-453.

AlMunajjed, M. (1997). Women in Saudi Arabia Today. United States: St. Martins Press. http://dx.doi.org/10.1057/9780230373105

Dewey, J. (1902). The Child and the Curriculum Including the School and Society. New York: Cosimo, Inc.

Elyas, T., \& Picard, M. (2013). Critiquing of Higher Education Policy in Saudi Arabia: Towards a New Neoliberalism. Education, Business and Society: Contemporary Middle Eastern Issues, 6, 31-41. http://dx.doi.org/10.1108/17537981311314709

Gordon, L. D. (1987). The Gibson Girl Goes to College: Popular Culture and Women's Higher Education in the Progressive Era, 1890-1920. American Quarterly, 39, 211-230. http://dx.doi.org/10.2307/2712910

Hakeem, A. A. A. A. (2012). Nedam Altaleem Wo Syasth [Education system and policy]. Cairo: Etrak.

Hamdan, A. (2005). Women and Education in Saudi Arabia: Challenges and Achievements. International Education Journal, 6, 42-64.

Lacey, R. (1981). The Kingdom: Arabia and the House of Saud. New York: Harcourt Brace Jovanovich.

Lloyd, C. B., Mensch, B. S., \& Clark, W. H. (2000). The Effects of Primary School Quality on School Dropout among Ke- 
nyan Girls and Boys. Comparative Education Review, 44, 113-147. http://dx.doi.org/10.1086/447600

Mashroa Almalek Abdullah Ltatwer Atalyem (2012). King Abdullah’s Project for Developing Public Education. http://www.tatweer.edu.sa/content/aboutus

Smith, D. E. (1987). The Everyday World as Problematic: A Feminist Sociology. Boston: Northwestern University Press.

Steele, C. M. (1997). A Threat in the Air: How Stereotypes Shape Intellectual Identity and Performance. American Psychologist, 52, 613. http://dx.doi.org/10.1037/0003-066X.52.6.613

Tanner, D., \& Tanner, L. N. (1975). Curriculum Development: Theory into Practice. New York, NY: Macmillan.

Ministry of Higher (2010). Women in Higher Education: Saudi Initiatives and Achievements. Riyadh: Ministry of Higher. 
Scientific Research Publishing (SCIRP) is one of the largest Open Access journal publishers. It is currently publishing more than 200 open access, online, peer-reviewed journals covering a wide range of academic disciplines. SCIRP serves the worldwide academic communities and contributes to the progress and application of science with its publication.

Other selected journals from SCIRP are listed as below. Submit your manuscript to us via either submit@scirp.org or Online Submission Portal.
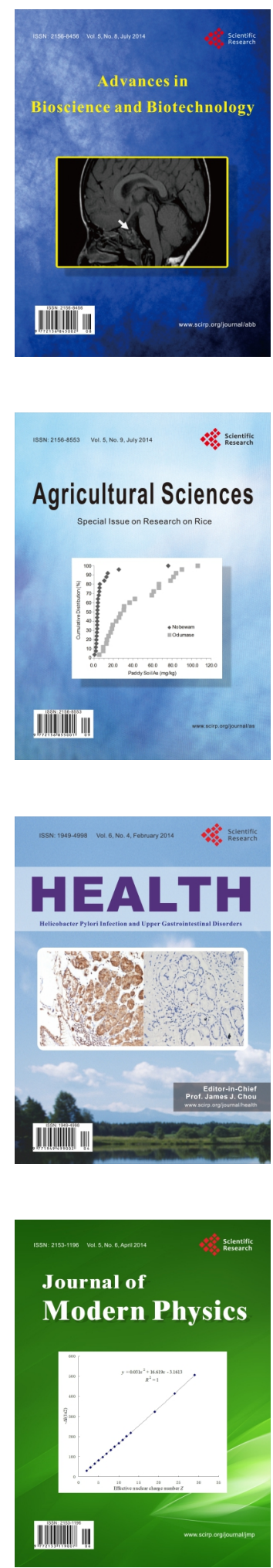
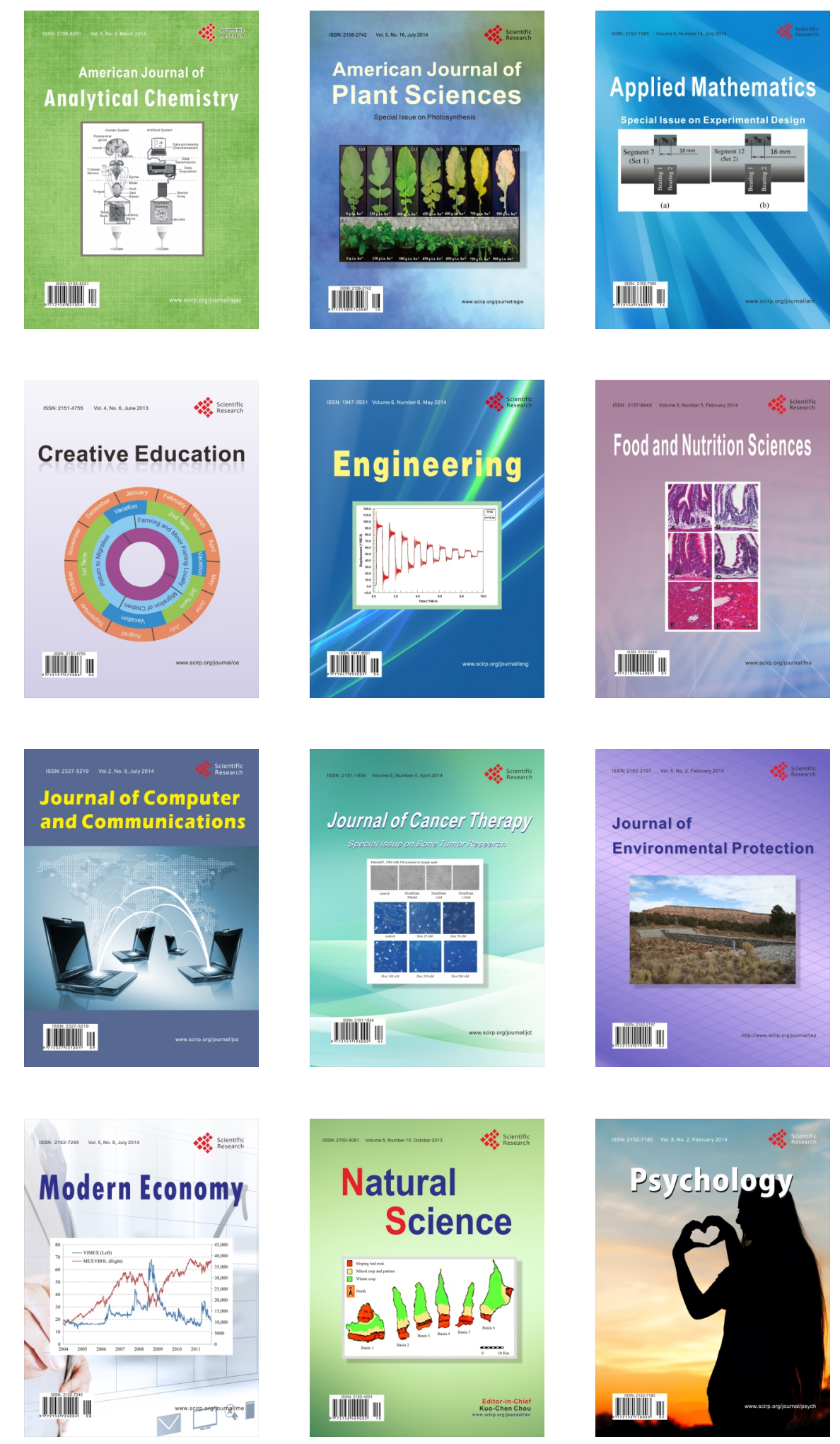